\title{
BIOLOGICAL STUDIES ON THE ANCHOVY, THRYSSA GAUTA- MIENSIS BABU RAO (PISCES: ENGRAULIDAE)
}

\author{
by
}

\author{
M. BABU RAO ${ }^{1)}$
}

\begin{abstract}
Biology of the anchovy, Thryssa gautamiensis BABU RAO, which forms a fishery in the Godavari estuary (East Coast of India) was studied for the three seasons, i.e. 1959-60, 1960-61 and 196162. The population pattern was studied during the three seasons by means of montly percentage length frequency curves and fitting normal curves. Length weight studies were made for the three seasons, the best fit equations to express the relationship have been calculated and differences of relationships within seasons have been tested. Relative condition (' $\left.\mathrm{Kn}^{\prime}\right)$ variation studies have been made for the different length groups of the fish for the two sexes. The variations of fecundity in relation to length and weight of fish respectively were studied and the equation to express their relationships have been established. The spawning season and the sizes, of ova at different stages of maturity have been determined by means of ova diameter measurement studies. The food preferences of this species have been ascertained by studying the gut contents and their item wise percentage frequencies in different months.
\end{abstract}

\section{INTRODUCTION}

Thryssa gautamiensis BABU RAO was first described from Godavari estuary (east coast of India) and found to form an important constituent of the fishery of that estuary (BABU RAO 1971). Observations made on the biology of this species from Godavari estuary during the period 1959-'62 are presented briefly in this paper. The estuary is flooded with rain water from the upper reaches from July to September and there will not be any fishing during that period in the estuary; consequently data could not be obtained in that season.

\section{MATERIAL AND METHODS}

Samples of Thryssa gautamiensis were obtained from the fishermen catches (boat seine, gillnet and small shore seines) at the fishing centers situated on the Gautami branch of the Godavari estuary (Fig. 1). Regular weekly samples were taken at Neelapalli and monthly samples were taken at Bhairavapalem, Balusutippa, Masakapalli and Kotipalli. The analysis of

1) Zoological Survey of India, Western Regional Station, 933/A, Shivaji Nagar, Poona - 16, India. 


\section{BABU RAO}

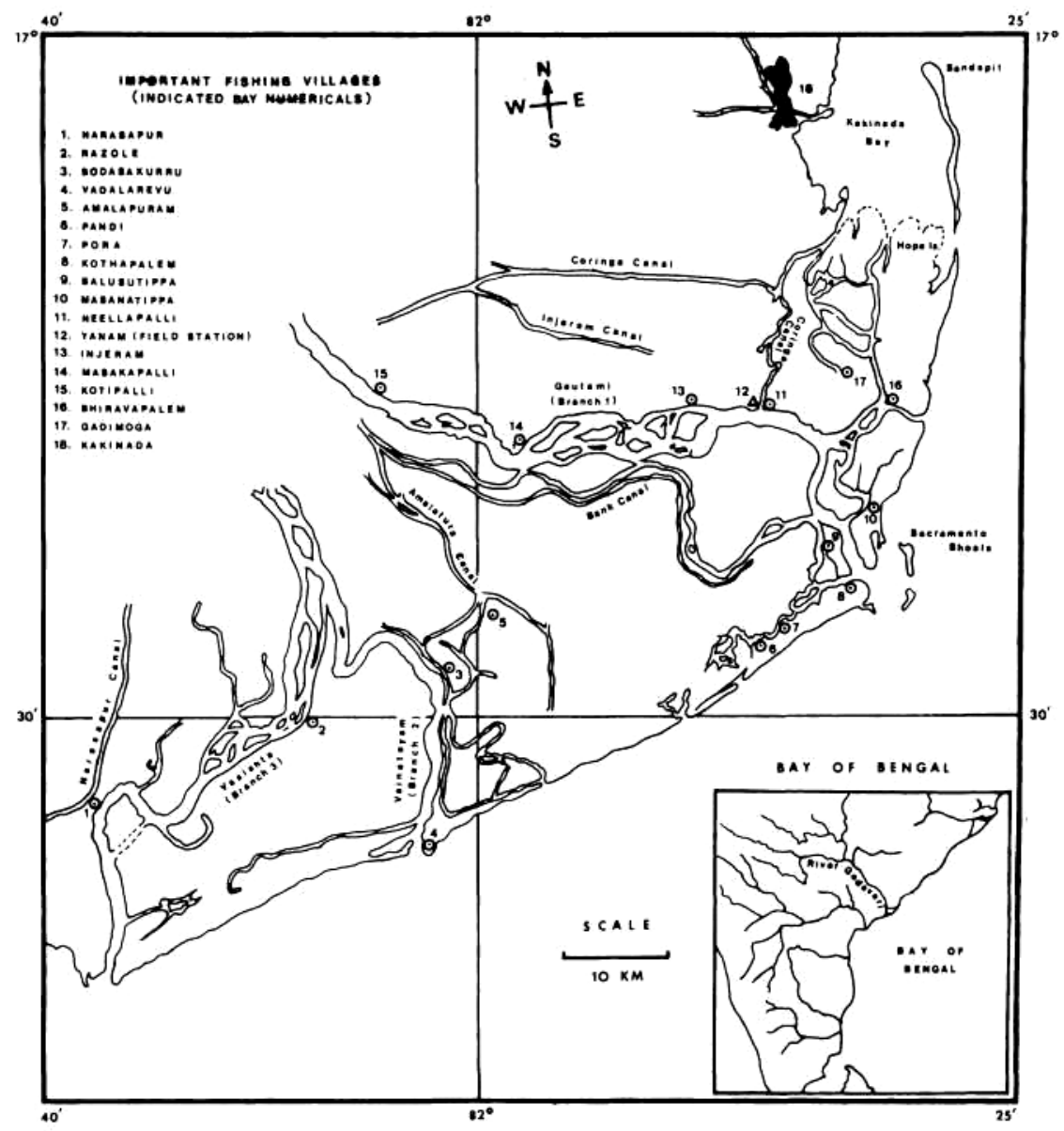

Figure 1. The Godavari estuary.

samples and the methods of study of the different biological aspects were, in general, the same as were followed in the case of Anodontostoma chacunda (BABU RAO 1965).

\section{BIOLOGY}

\section{Length frequency studies}

Length frequency data obtained from the samples were pooled monthwise for the years 1959-'6O, 1960-'61 and 1961-'62 (Table 1). It can be seen that no regular growth pattern is discernable in any of the three years, indicating that spawning period was extended. When normal curves 
BIOLOGICAL STUDIES ON THE ANCHOVY

TABLE I. Centimeter length groups in different months of the three seasons 1959-'60, 1960-'61 and 1961-'62.

(A) 1959-1960 Season

\begin{tabular}{|c|c|c|c|c|c|c|c|c|}
\hline \multirow{2}{*}{$\begin{array}{l}\text { Length } \\
\text { in } \mathrm{CM} \text {. }\end{array}$} & \multicolumn{8}{|c|}{ Number of Specimens } \\
\hline & $\begin{array}{l}\text { Nov. } \\
1959\end{array}$ & $\begin{array}{c}\text { Dec } \\
1960\end{array}$ & $\begin{array}{r}\text { Jan. } \\
1960\end{array}$ & $\begin{array}{l}\text { Feb. } \\
1960\end{array}$ & $\begin{array}{l}\text { March } \\
1960\end{array}$ & $\begin{array}{l}\text { April } \\
1960\end{array}$ & $\begin{array}{l}\text { May } \\
1960\end{array}$ & $\begin{array}{l}\text { June } \\
1960\end{array}$ \\
\hline 6 & & & & 1 & & & & 5 \\
\hline 7 & & & & 1 & & & & 14 \\
\hline 8 & & & & 3 & & & & 20 \\
\hline 9 & & & & - & & & & 6 \\
\hline 10 & & 1 & & , & & & & 11 \\
\hline 11 & & - & & $\mathbf{1}$ & & 1 & & 6 \\
\hline 12 & & & & 1 & & 1 & & 11 \\
\hline 13 & & 1 & & - & 5 & 6 & 2 & 23 \\
\hline 14 & & - & & - & 2 & 17 & 10 & 11 \\
\hline 15 & 4 & 2 & 1 & 3 & 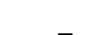 & 12 & 17 & 8 \\
\hline 16 & 6 & 6 & 4 & 4 & - & 3 & 11 & 3 \\
\hline 17 & 7 & 1 & 1 & 11 & - & & & 2 \\
\hline 18 & 5 & 1 & 1 & 2 & _ & & & \\
\hline 19 & 10 & _ & 2 & 2 & & & & \\
\hline 20 & 8 & 3 & 3 & 2 & 1 & & & \\
\hline 21 & 6 & 5 & 1 & 3 & 2 & & & \\
\hline 22 & 9 & 2 & 1 & & & & & \\
\hline 23 & 4 & 1 & 7 & & & & & \\
\hline 24 & 4 & & 4 & & & & & \\
\hline 25 & 1 & & & & & & & \\
\hline
\end{tabular}

(B) 1960 - 1961 Season

\begin{tabular}{|c|c|c|c|c|c|c|c|c|c|}
\hline \multirow{2}{*}{$\begin{array}{l}\text { Length } \\
\text { in } \mathrm{CM} \text {. }\end{array}$} & \multicolumn{9}{|c|}{ Number of Specimens } \\
\hline & $\begin{array}{c}\text { Oct. } \\
1960\end{array}$ & $\begin{array}{l}\text { Nov. } \\
1960\end{array}$ & $\begin{array}{c}\text { Dec. } \\
1960\end{array}$ & $\begin{array}{l}\text { Jan. } \\
1961\end{array}$ & $\begin{array}{l}\text { Feb. } \\
1961\end{array}$ & $\begin{array}{c}\text { March } \\
1961\end{array}$ & $\begin{array}{c}\text { April } \\
1961\end{array}$ & $\begin{array}{l}\text { May } \\
1961\end{array}$ & $\begin{array}{l}\text { June } \\
1961\end{array}$ \\
\hline 10 & & & & & & & & 1 & 1 \\
\hline 11 & 3 & & & & & & & 2 & 2 \\
\hline 12 & 12 & & 1 & & & 6 & 3 & 18 & 3 \\
\hline 13 & 9 & 1 & - & & & 10 & 8 & 22 & 5 \\
\hline 14 & 4 & 1 & 2 & 4 & 2 & 10 & 21 & 24 & 6 \\
\hline 15 & 5 & 2 & 10 & 2 & 3 & 10 & 23 & 15 & 6 \\
\hline 16 & 2 & 18 & 12 & 7 & 3 & 5 & 17 & 4 & 2 \\
\hline 17 & - & 20 & 19 & 4 & 1 & 11 & 15 & 6 & 2 \\
\hline 18 & - & 25 & 11 & - & - & 7 & 11 & 2 & - \\
\hline 19 & 2 & 14 & 14 & 3 & 2 & 4 & 2 & & - \\
\hline 20 & 2 & 8 & 4 & - & 3 & 4 & 3 & & 1 \\
\hline 21 & - & 3 & 4 & 1 & 6 & 7 & 1 & & 1 \\
\hline 22 & - & 1 & - & & 2 & 4 & 1 & & 1 \\
\hline 23 & 1 & 4 & 1 & & 1 & - & 1 & & \\
\hline 24 & & - & & & & 1 & & & \\
\hline 25 & & 1 & & & & & & & \\
\hline
\end{tabular}


M. BABU RAO

Table I continued

(C) 1961-1962 Season

\begin{tabular}{lccccccccc}
\hline Length & \multicolumn{7}{c}{ Number of Specimens } \\
\hline in CM. & Nov. & Dec. & Jan. & Feb. & March & April & May & June & July \\
& 1961 & 1961 & 1962 & 1962 & 1962 & 1962 & 1962 & 1962 & 1962 \\
\hline 9 & 1 & & & & & & & & \\
10 & 8 & & & & & & & & \\
11 & 8 & & & & & 1 & 1 & & 1 \\
12 & 12 & & & & & - & - & 5 & 4 \\
13 & 10 & & & & & 3 & 2 & 22 & 2 \\
14 & 2 & & & & 1 & 6 & 6 & 18 & 8 \\
15 & 3 & & & & 8 & 5 & 14 & 12 & 7 \\
16 & 5 & & 3 & & 24 & 8 & 12 & 7 & 4 \\
17 & 10 & 2 & 2 & 1 & 23 & 9 & 10 & 7 & 1 \\
18 & 14 & - & 8 & 4 & 10 & - & 6 & 6 & - \\
19 & 28 & 7 & 27 & 9 & 2 & 2 & - & & 1 \\
20 & 21 & 10 & 10 & 10 & 9 & 3 & 2 & & - \\
21 & 11 & 17 & 7 & 5 & 9 & 4 & & & 1 \\
22 & 9 & 35 & - & 3 & - & - & & & $\mathbf{2}$ \\
23 & 13 & 36 & 1 & 1 & 4 & - & & & 3 \\
24 & 3 & 13 & & & & 1 & & & \\
25 & 3 & 5 & & & & & & & \\
26 & & 1 & & & & & & & \\
\hline
\end{tabular}

were fitted to the percentage frequency curves of the 1961 '62 samples (HARDING 1949; CASSIE1954), it was found that the frequency curve of each month can be split up into several normal curves indicating the existence of many populations, which were the offspring of broods of different periods (Fig. 2), substantiating the contention that spawning was somewhat prolonged in this species. In general, it is evident from the percentage frequency curves of the three years that majority of adults occur during November February period and majority of juveniles occur in March - July period. Since floods set in the estuary from July onwards and extend up to September October period, this species, along with many other estuarine species, does not form fishery in the estuary during this period. Perhaps many of the estuarine fishes restrict themselves to the river mouth region during the floods, in view of the fact that the estuary is full of fresh water with little salinity (BABU RAO 1964, 1965).

\section{Length weight relationship}

Length and weight data were obtained for over 800 specimens during the period 1959 to 1962 , covering three seasons. Averages of lengths and weights were obtained for each centimeter length groups (Table IV). Three 
BIOLOGICAL STUDIES ON THE ANCHOVY

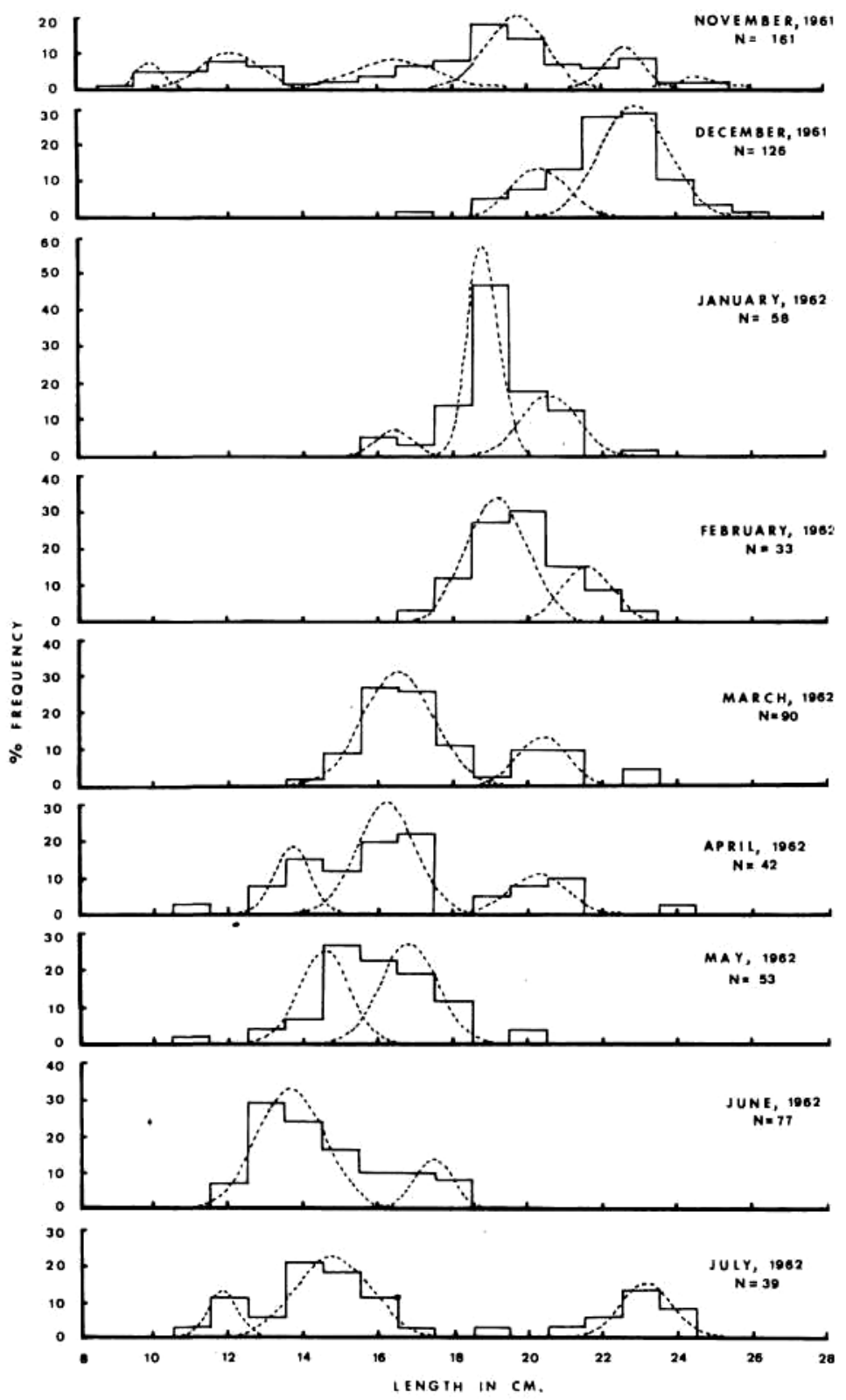

Figure 2. Normal curves fitted to-monthly percentage length frequencies for 1961-'62 season. 


\begin{tabular}{|c|c|c|c|c|c|c|c|c|c|c|c|c|}
\hline \multirow{2}{*}{$\begin{array}{l}\text { Sl } \\
\text { No. }\end{array}$} & \multicolumn{4}{|c|}{$1959-‘ 60$ season } & \multicolumn{4}{|c|}{$1960-` 61$ season } & \multicolumn{4}{|c|}{$1961-^{6} 62$ season } \\
\hline & $\begin{array}{c}\text { No of } \\
\text { Specimens } \\
\text { Studied }\end{array}$ & $\begin{array}{c}\text { Average } \\
\text { of } \\
\text { Total } \\
\text { length }\end{array}$ & $\begin{array}{c}\text { Average } \\
\text { observed } \\
\text { weight }\end{array}$ & $\begin{array}{c}\text { Calculated } \\
\text { weight }\end{array}$ & $\begin{array}{l}\text { No. of } \\
\text { Specimens } \\
\text { Studied }\end{array}$ & $\begin{array}{c}\text { Average } \\
\text { Total } \\
\text { length }\end{array}$ & $\begin{array}{c}\text { Average } \\
\text { observed } \\
\text { weight }\end{array}$ & $\begin{array}{c}\text { Calculated } \\
\text { weight }\end{array}$ & $\begin{array}{c}\text { No. of } \\
\text { Specimens } \\
\text { Studied }\end{array}$ & $\begin{array}{c}\text { Average } \\
\text { Total } \\
\text { length }\end{array}$ & $\begin{array}{c}\text { Average } \\
\text { observed } \\
\text { weight }\end{array}$ & $\begin{array}{c}\text { Calculated } \\
\text { weight }\end{array}$ \\
\hline 1 & 12 & 8.46 & 2.71 & 2.14 & 6 & 11.65 & 9.58 & 8.39 & 2 & 13.70 & 14.50 & 14.22 \\
\hline 2 & 5 & 9.37 & 4.30 & 4.10 & 29 & 12.57 & 11.97 & 11.23 & 3 & 14.53 & 18.33 & 17.85 \\
\hline 3 & 9 & 10.46 & 6.50 & 6.03 & 29 & 13.46 & 14.41 & 14.40 & 16 & 15.36 & 22.25 & 21.90 \\
\hline 4 & 6 & 11.38 & 9.17 & 8.41 & 36 & 14.47 & 18.14 & 18.56 & 30 & 16.51 & 27.10 & 28.31 \\
\hline 5 & 8 & 12.58 & 12.89 & 12.15 & 35 & 15.45 & 22.97 & 23.17 & 20 & 17.45 & 35.75 & 34.22 \\
\hline 6 & 11 & 13.56 & 15.41 & 15.77 & 35 & 16.52 & 29.43 & 28.94 & 20 & 18.48 & 41.40 & 41.52 \\
\hline 7 & 20 & 14.54 & 19.33 & 19.98 & 35 & 17.37 & 33.37 & 34.06 & 30 & 19.53 & 48.57 & 49.83 \\
\hline 8 & 23 & 15.53 & 23.76 & 24.82 & 35 & 18.48 & 41.03 & 41.60 & 30 & 20.43 & 57.13 & 57.67 \\
\hline 9 & 24 & 16.47 & 30.48 & 30.02 & 30 & 19.41 & 48.46 & 48.63 & 30 & 21.30 & 66.30 & 66.00 \\
\hline 10 & 20 & 17.35 & 34.60 & 35.46 & 20 & 20.30 & 53.70 & 56.03 & 30 & 22.46 & 78.20 & 78.14 \\
\hline 11 & 10 & 18.31 & 41.40 & 42.11 & 20 & 21.41 & 66.50 & 66.20 & 30 & 23.38 & 88.43 & 88.78 \\
\hline 12 & 13 & 19.54 & 51.00 & 51.65 & 8 & 22.48 & 77.13 & 76.90 & 10 & 24.34 & 99.00 & 100.65 \\
\hline 13 & 13 & 20.38 & 57.30 & 58.65 & 8 & 23.38 & 88.13 & 87.04 & 5 & 25.12 & 113.40 & 111.15 \\
\hline 14 & 14 & 21.43 & 68.64 & 68.89 & & & & & & & & \\
\hline 15 & 12 & 22.42 & 82.17 & 79.14 & & & & & & & & \\
\hline 16 & 11 & 23.36 & 90.36 & 89.85 & & & & & & & & \\
\hline 17 & 8 & 24.19 & 99.25 & 100.10 & & & & & & & & \\
\hline
\end{tabular}




\section{BIOLOGICAL STUDIES ON THE ANCHOVY}

equations were applied to the pooled length weight data to express the length weight relationship (Fig. 3). The equation $\mathrm{W}=\mathrm{a}+\mathrm{b} \cdot \mathrm{L}^{3}$ was found to have the least sum of squared differences between observed and calculated weights (Table II) and hence taken as the equation expressing the lenght-weight relationship in the species. The equations for the individual seasons were calculated (Table III). When the length weight data of the three seasons were subjected to analysis of covariance it was found that the three seasons were not homogenous in expressing the relationship (Table V). The three seasons were taken pairwise and the significance test was applied to see which seasons differ significantly (Table VI). It was found that I960-'61 seasons significantly differs from the rest of the two seasons in having a low regression coefficient. 1959-'60 and 1961-'62 seasons did not differ from one another significantly (Fig. 4). The low regression coefficient in 1960 -'61 season indicates a lower rate of increase of weight with length in this season when compared to the other seasons. This might be due to the generally poor occurrence of plankton (which forms the food of this species) during this season than the other two seasons (BABU RAO 1964).

\section{Relative condition ('Kn')}

Relative condition values of the specimens for the three seasons were obtained by dividing the observed weight by the calculated weight, which in turn is obtained by applying the respective length-weight equation of each season (LE CREN 1951; PILLAY 1958; BABU RAO 1965).

Monthly geometric mean 'Kn' values were calculated (Table VII) and plotted for the three seasons (Fig. 5). It was found that 'Kn' fluctuates throughout the season; however relatively higher ' $\mathrm{Kn}$ ' values were obtained during September to January from whence it was found to decrease through February, March and April. From the month of May onwards an increase in the ' $\mathrm{Kn}$ ' can be noticeable. This indicates that though spawning is prolonged, from September to January, maturing or fully mature specimens occur, intense spawning being taking place from February to April.

Geometric mean ' $\mathrm{Kn}$ ' values were also obtained for the females at various lengths for the three seasons (Table VIII) and plotted (Fig. 5). It was found that from about $16 \mathrm{~cm}$ onwards the 'Kn' values fluctuate till the end. As was shown later, since maturing ovaries have a significant influence on the relative condition of females, it is clear that presence of mature and spent females right from $16 \mathrm{~cm}$ onwards, resulted in the fluctuation of ' $\mathrm{kn}$ ' values from $16 \mathrm{~cm}$ onwards. It appears that this species breeds more than once in its life time and that breeding starts from $16 \mathrm{~cm}$ onwards. The high ' $\mathrm{Kn}$ ' values indicating the presence of more number of mature females in the res- 


\section{BABU RAO}

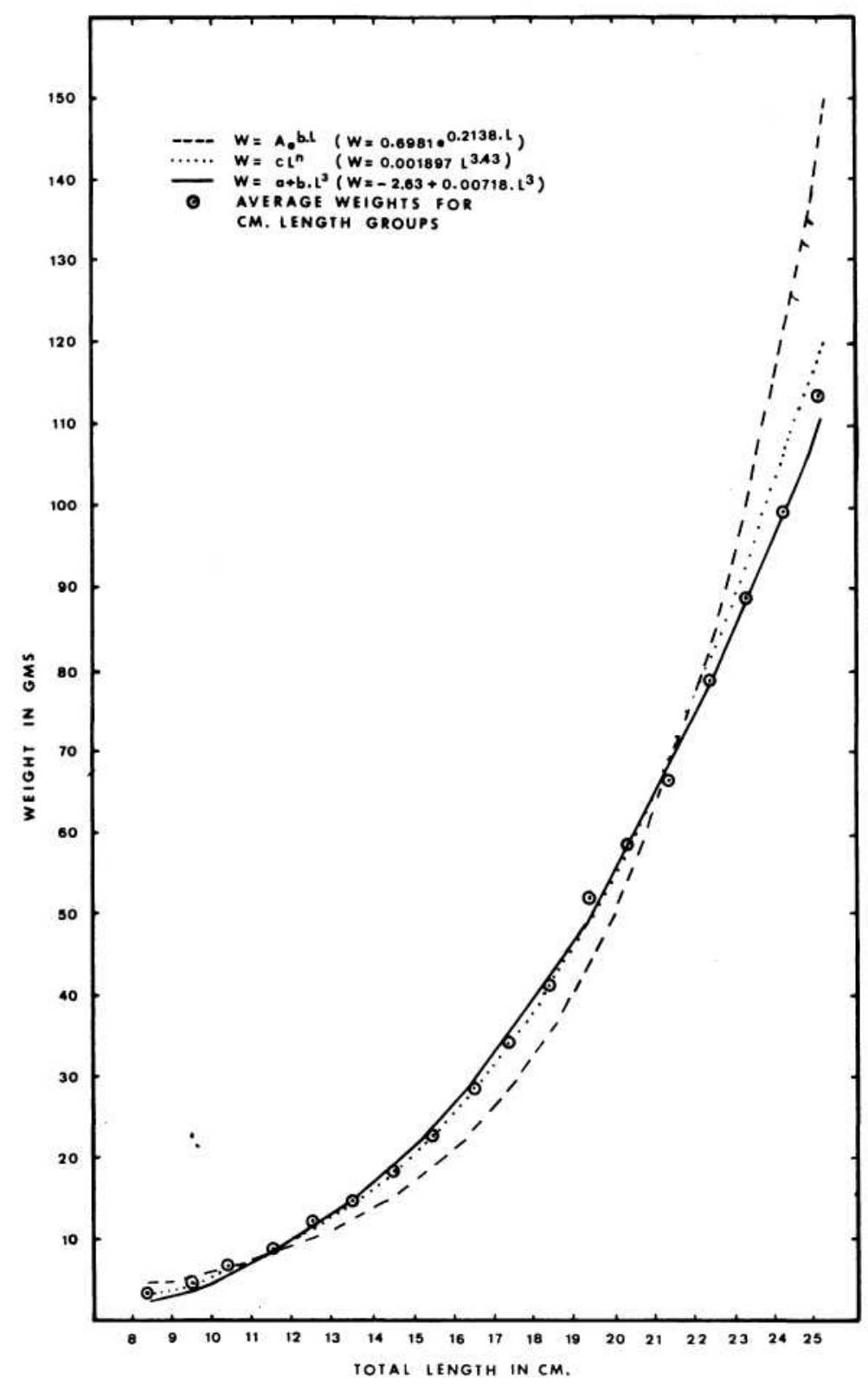

Figure 3. Length-Weight relationship for the pooled data of the three seasons. 
BIOLOGICAL STUDIES ON THE ANCHOVY

$\begin{array}{llllllllllllllll}1 & 2 & 3 & \begin{array}{c}4 \\ \text { CUBE }\end{array} & 5 & 6 & 7 & 8 & 9 & 10 & 11 & 12 & 13 & 14 & 15 & 16\end{array}$

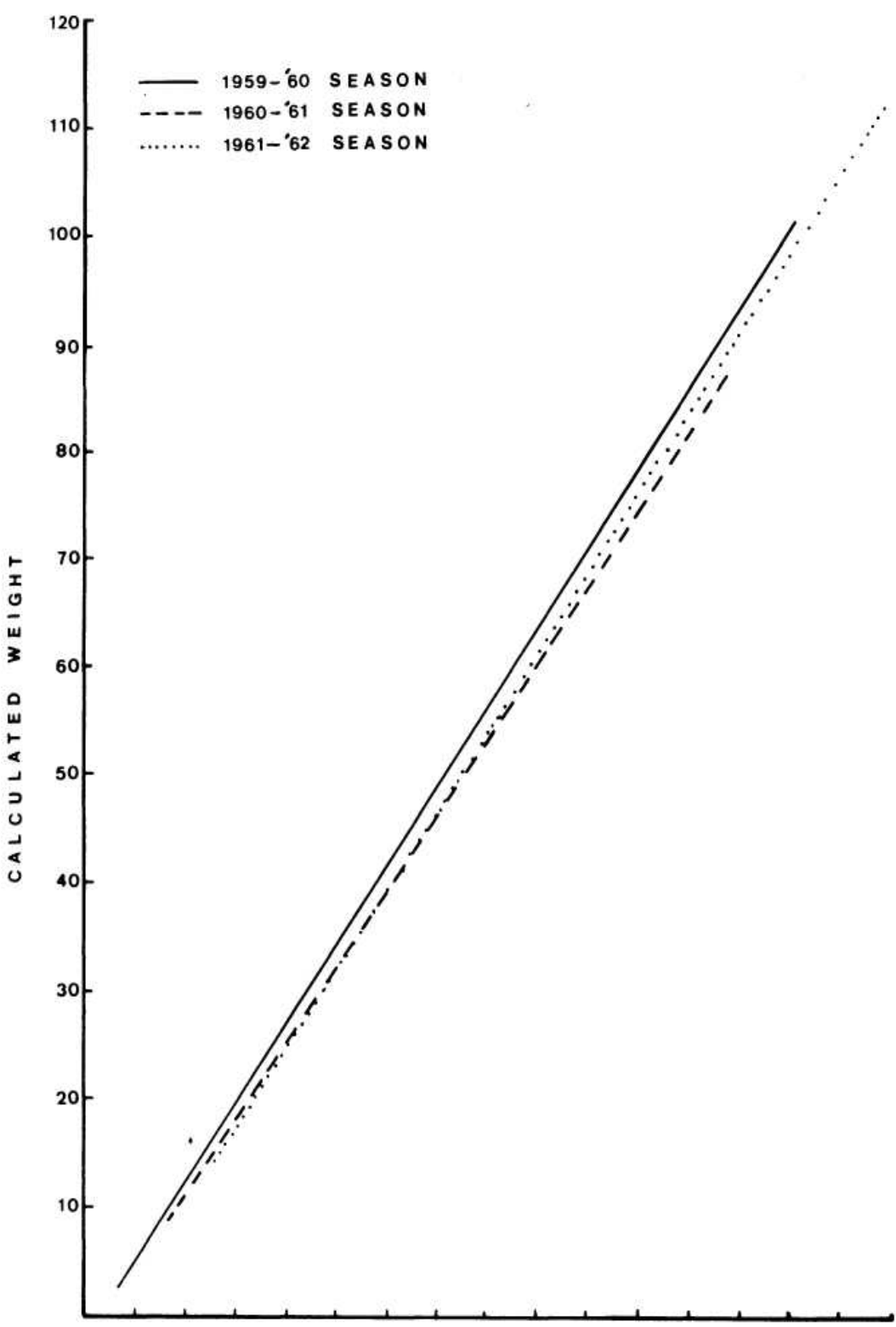

Figure 4. Cube of Length-weight relationship for the three seasons. 


\section{BABU RAO}
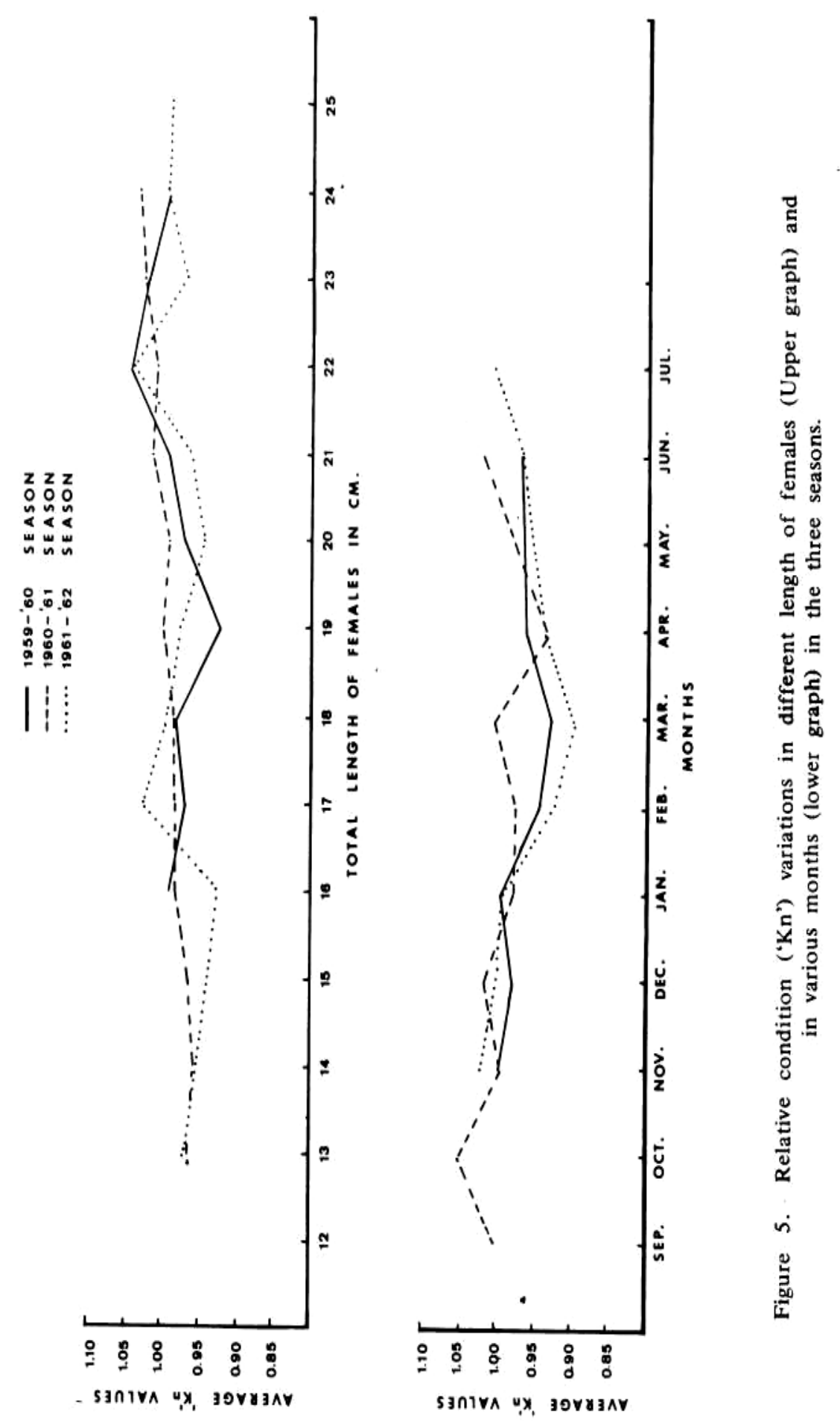
BIOLOGICAL STUDIES ON THE ANCHOVY

TABLE II. Sum of squared differences between observed and calculated weights for the length - weight equations.

\begin{tabular}{cc}
\hline Equation & $\Sigma\left(\mathrm{W}_{\mathrm{o}}-\mathrm{W}_{\mathrm{c}}\right)^{2}$ \\
\hline $\mathrm{W}=\mathrm{cL}^{\mathrm{n}}\left(\mathrm{W}=\mathrm{a} \cdot \mathrm{L}^{\mathrm{b}}\right)$ & 161.8573 \\
$\mathrm{~W}=\mathrm{Ae}^{\mathrm{b} \cdot \mathrm{L}^{2}}$ & $2,492.2165$ \\
$\mathrm{~W}=\mathrm{a}+\mathrm{b} \cdot \mathrm{L}^{3}$ & 16.9751 \\
\hline
\end{tabular}

TABLE III. Equations expressing length and weight of the pooled data and of different seasons

\begin{tabular}{lccl}
\hline Season & $\mathbf{n}$ & \multicolumn{1}{l}{$\begin{array}{l}\text { Length } \\
\text { range } \\
\text { in cm. }\end{array}$} & Equation \\
\hline Pooled data & 808 & $8-25$ & $\mathrm{~W}=-2.63+0.00718 . \mathrm{L}^{3}$ \\
$1959-60$ & 219 & $8-24$ & $\mathrm{~W}=-2.23+0.007223 . \mathrm{L}^{3}$ \\
$1960-61$ & 326 & $11-23$ & $\mathrm{~W}=-2.57+0.006998 . \mathrm{L}^{3}$ \\
$1961-62$ & 264 & $13-25$ & $\mathrm{~W}=-4.55+0.0073 . \mathrm{L}^{3}$
\end{tabular}

pective length range and the low ' $\mathrm{Kn}$ ' value indicating the presence of more number of spent females in the respective length range.

Mean relative condition were also calculated for the various maturity stages of the females for the three seasons (Table IX). It can be seen that in all the three seasons relative condition steadily increases from Stage II to Stage VI of maturity through the intermediate stages and suddenly falls in the spent individuals (Fig. 6). Highest relative condition is encountered in
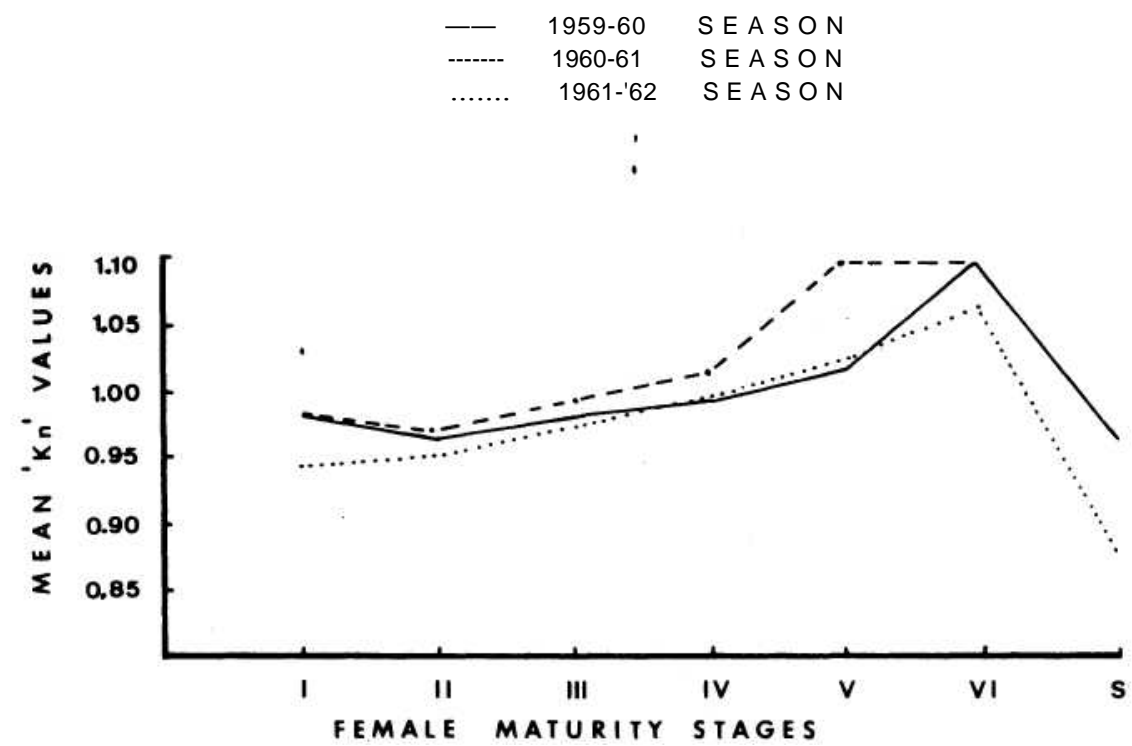

Figure 6. Relative condition ('Kn') variations in different female maturity stages in the three seasons. 
TABLE V. Analysis of Covariance of length-weight data of different seasons to test the homogeniety of the relationship.

\begin{tabular}{lcccccccc}
\hline Seasons & $(1)$ & $(2)$ & $(3)$ & $(4)$ & $(5)$ & (6) & $(7)$ & $(8)$ \\
& $\mathbf{D . F}$ & $\sum(\mathbf{X}-\mathbf{X})^{\mathbf{2}}$ & $\sum(\mathbf{x}-\mathbf{x})(\mathbf{y}-\mathbf{y})$ & $\sum(\mathbf{Y}-\mathbf{Y})^{\mathbf{2}}$ & $\mathbf{b}$ & $\sum(\mathbf{x}-\mathbf{x})(\mathbf{y}-\mathbf{y})$ & $\sum \mathbf{2} \mathbf{Y}^{\prime 2}$ & $\mathbf{D . F}^{2}$ \\
\hline $1959-60$ & 16 & $304,685,100$ & $2,201,321$ & 15,903 & 0.007223 & 15,900 & 3 \\
$1960-' 61$ & 12 & $161,830,810$ & $1,132,207$ & 7,939 & 0.006998 & 7,923 & 15 \\
1961 -'62 & 12 & $235,319,500$ & $1,718,063$ & 12,563 & 0.007300 & 12,541 & 11 \\
\hline Totals & $\mathbf{4 0}$ & $\mathbf{7 0 1 , 8 3 5 , 4 1 0}$ & $\mathbf{5 , 0 5 1 , 5 9 1}$ & $\mathbf{3 6 , 4 0 5}$ & $\mathbf{0 . 0 0 7 1 9 9}$ & $\mathbf{3 6 , 3 6 6}$ & $\mathbf{3 9}$ & $\mathbf{3 9}$ \\
\hline
\end{tabular}

(1) D.F. for unadjusted sums of squares (2) S.S. of V variate (3) Sums of products (4) S.S. of ' $y$ ' variate (5) regression Coefficients (7) adjusted sums of squares (8) D.F. for adjusted sums of squares.

\begin{tabular}{lcccccc}
\hline & D.F & $\begin{array}{c}\text { Adjusted } \\
\text { S.S. }\end{array}$ & Variance & F & P & Significance \\
\hline Totals & 39 & 39 & & & & \\
Seasons & 37 & 31 & $\mathbf{0 . 8 3 7 8}(\mathrm{Vi})$ & 4.775 & $<0.05$ & Significant \\
Difference & $\mathbf{8}$ & $\mathbf{2}$ & $\mathbf{4 . 0 0 0 0}\left(\mathrm{V}_{2}\right)$ & & \\
\hline
\end{tabular}

The notation is as given by GOULDEN (1939) 
TABLE VI. Test of significance of the difference between regression coefficients between the different seasons, in the length weight relationship.

\begin{tabular}{llll}
\hline & $\begin{array}{l}\text { Between 1959-'60 } \\
\text { and 1960-'61 } \\
\text { seasons }\end{array}$ & $\begin{array}{l}\text { Between 1960-'61 } \\
\text { and 1961-'62 } \\
\text { seasons }\end{array}$ & $\begin{array}{l}\text { Between 1961-'62 } \\
\text { and 1959-'60 } \\
\text { seasons }\end{array}$ \\
\hline $\begin{array}{l}\text { Standard error of difference } \\
\text { of the regression coefficients }\end{array}$ & 0.00009636 & 0.0001041 & 0.00009679 \\
$\begin{array}{l}\text { Difference in the regression } \\
\text { Coefficients }\end{array}$ & $\mathbf{0 . 0 0 0 2 2 5}$ & & 0.00077 \\
t & 2.335 & 0.000302 & 0.7956 \\
degrees of freedom & 26 & 2.901 & 26 \\
Probability & $<0.05$ & 22 & $>0.10$ \\
Significance & Significant & $<0.01$ & Not significant \\
\hline
\end{tabular}




\section{M.BABU RAO}

TABLE VII. Mean 'Kn' values (Relative condition) at different months during the three seasons

\begin{tabular}{|c|c|c|c|c|c|c|}
\hline & \multicolumn{2}{|c|}{ 1959-'6O season } & \multicolumn{2}{|c|}{ 1960-61 season } & \multicolumn{2}{|c|}{ 1961-'6 2 season } \\
\hline & $\mathbf{n}$ & Mean 'Kn' & $\mathbf{n}$ & Mean 'Kn' & $\mathbf{n}$ & Mean 'Kn' \\
\hline September & & & 9 & 1.0040 & & \\
\hline $\begin{array}{l}\text { October } \\
\text { November }\end{array}$ & 62 & 0.9988 & $\begin{array}{l}35 \\
71\end{array}$ & $\begin{array}{l}1.0510 \\
0.9970\end{array}$ & 108 & 1.0230 \\
\hline December & 21 & 0.9797 & 64 & 1.0170 & 109 & 1.0020 \\
\hline January & 25 & 0.9982 & 20 & 0.9768 & 64 & 0.9926 \\
\hline February & 30 & 0.9445 & 19 & 0.9783 & 31 & 0.9251 \\
\hline March & 11 & 0.9272 & 73 & 1.0040 & 95 & 0.8984 \\
\hline April & 34 & 0.9610 & 88 & 0.9309 & 35 & 0.9358 \\
\hline May & 35 & 0.9668 & ' 57 & 0.9757 & 54 & 0.9548 \\
\hline June & 42 & 0.9661 & 44 & 1.0200 & 60 & 0.9651 \\
\hline July & & & & & 37 & 1.0060 \\
\hline
\end{tabular}

TABLE VIII. Mean 'Kn' values (Relative condition) of different length groups of females during the three seasons.

\begin{tabular}{|c|c|c|c|c|c|c|}
\hline \multirow[b]{2}{*}{$\begin{array}{l}\text { Length range of } \\
\text { females in } \mathrm{cm} \text {. }\end{array}$} & \multicolumn{2}{|c|}{ 1959 '6O season } & \multirow{2}{*}{$\frac{1960-}{n}$} & \multirow{2}{*}{$\begin{array}{l}\text {-'61 season } \\
\text { Mean 'Kn' }\end{array}$} & \multirow{2}{*}{$\frac{1961-}{n}$} & \multirow{2}{*}{$\begin{array}{l}\text {-'62 season } \\
\text { Mean 'Kn' }\end{array}$} \\
\hline & $\mathrm{n}$ & Mean 'Kn' & & & & \\
\hline 12.00- 12.99 & & & 4 & 1.0820 & & \\
\hline $13.00-13.99$ & & & 10 & 0.9665 & 3 & 0.9785 \\
\hline $14.00-14.99$ & & & 14 & 0.9598 & 6 & 0.9579 \\
\hline $15.00-15.99$ & & & 23 & 0.9658 & 10 & 0.9421 \\
\hline $16.00-16.99$ & 4 & 0.9919 & 18 & 0.9819 & 9 & 0.9260 \\
\hline $17.00-17.99$ & 3 & 0.9712 & 26 & 0.9847 & 15 & 1.0260 \\
\hline $18.00-18.99$ & 8 & 0.9809 & 29 & 0.9858 & 20 & 0.9949 \\
\hline $19.00-19.99$ & 4 & 0.9262 & 27 & 1.0000 & 57 & 0.9768 \\
\hline $20.00-20.99$ & 9 & 0.9714 & 17 & 0.9924 & 43 & 0.9488 \\
\hline $21.00-21.99$ & 12 & 0.9911 & 24 & 1.0160 & 41 & 0.9654 \\
\hline $22.00-22.99$ & 10 & 1.0410 & 11 & 1.0100 & 44 & 1.0040 \\
\hline $23.00-23.99$ & 11 & 1.0020 & 10 & 1.0240 & 46 & 0.9929 \\
\hline $24.00-24.99$ & 8 & 0.9913 & 4 & 1.0330 & 17 & 0.9924 \\
\hline $25.00-25.99$ & & & & & 7 & 0.9924 \\
\hline
\end{tabular}

TABLE IX. Mean 'Kn' values (Relative condition) at different female maturity stages during the threeseasons.

\begin{tabular}{|c|c|c|c|c|c|c|}
\hline \multirow{2}{*}{$\begin{array}{c}\text { Female maturity } \\
\text { stages }\end{array}$} & \multicolumn{2}{|c|}{ 1959-'60 season } & \multirow{2}{*}{$\begin{array}{l}\text { 1960-'61 } \\
n\end{array}$} & \multirow{2}{*}{$\begin{array}{l}\text { season } \\
\text { Mean 'Kn' }\end{array}$} & \multicolumn{2}{|c|}{ 1961-'62 season } \\
\hline & $\mathbf{n}$ & Mean 'Kn' & & & $\mathbf{n}$ & Mean 'Kn' \\
\hline Stage I & 8 & 0.9811 & 101 & 0.9826 & 120 & 0.9486 \\
\hline Stage II & 15 & 0.9649 & 75 & 0.9725 & 40 & 0.9504 \\
\hline Stage III & 12 & 0.9828 & 40 & 0.9988 & 42 & 0.9736 \\
\hline Stage IV & 18 & 0.9922 & 21 & 1.0150 & 50 & 0.9993 \\
\hline Stage V & 9 & 1.0170 & 12 & 1.0970 & 87 & 1.0270 \\
\hline Stage VI & 6 & 1.0960 & 3 & 1.0970 & 13 & 1.0650 \\
\hline Spent & 4 & 0.9656 & & & 3 & 0.8843 \\
\hline
\end{tabular}




\section{BIOLOGICAL STUDIES ON THE ANCHOVY}

Stages V and VI of maturity. It is evident from this that in this species maturity of ovaries plays an important role in the relative condition of the females.

\section{Fecundity}

Female specimens in the Stages V and VI of maturity were selected for fecundity studies in the three seasons. Fecundity was estimated by volumetric method (BABU RAO 1965). Total length of fish and total weight of the fish on one hand and fecundity on the other were plotted and the relationship was expressed by a closely fitting curve and a corresponding equation for the three seasons (Table X - XIII, Figs. 7-12). The cube equation $\mathrm{F}=\mathrm{a}+\mathrm{b} \cdot \mathrm{L}^{3}$ was found to be suitable for expressing the total length and fecundity relationship and the linear regression equation $\mathrm{F}=\mathrm{a}+$ b.W was found to be suitable for expressing the weight of the fish and fecundity relationship (Table XIV). It can also be seen from Figure 11 that the females become mature from $16 \mathrm{~cm}$ onwards and capable of breeding till they attain a length of about $25 \mathrm{~cm}$. This confirms the conclusions drawn in the relative condition variations study (op. cit.) that in females breeding is rather prolonged starting from $16 \mathrm{~cm}$ onwards.

\section{Ova diameter measurement studies}

Ovarian eggs of the different maturity stages occurring in the various length groups of the species in the 1961- '62 season, were measured and their percentage frequencies were plotted (Fig. 13). It is interesting to note that fully mature specimens (Stage VI) were encountered in various length groups starting from $17 \mathrm{~cm}$ group onwards, indicating that the species mature more than once in their life time and growth has no effect on the maturity and spawning of the individuals. This accounts for the ocurrence of various maturity stages from $16-17 \mathrm{~cm}$ onwards and since maturity has definite effect on the relative condition in the females (Fig. 6), it also explains the fluctuations in the relative condition from $16 \mathrm{~cm}$ onwards, in the females (Fig. 5). This also confirms the earlier observations that spawning is a prolonged process in view of the occurrence of mature ovaries during the different stages of growth.

From Fig. 13 it can also be established the size of ova at different stages of maturity: $0.40-0.50 \mathrm{~mm}$ in Stage III, $0.60-0.70 \mathrm{~mm}$ in Stage IV, 0.70 $-0.80 \mathrm{~mm}$ in Stage V and $1.00-1.40 \mathrm{~mm}$ in Stage VI. The ova become nearly double the size when they enter into Stages VI from Stage V of maturity, due to the absorption of water; the eggs in Stage V are opaque, solid and light yellowish in colour, while in Stage VI they become 


\section{M.BABU RAO}

translucent and delicate (due to water content) and resemble the planktonic eggs in all features except in size.

\section{Food}

The food preference of this species was ascertained by a study of the percentage frequency of the guts containing various food organisms in different months for the 1960-'61 season (occurrence method). The

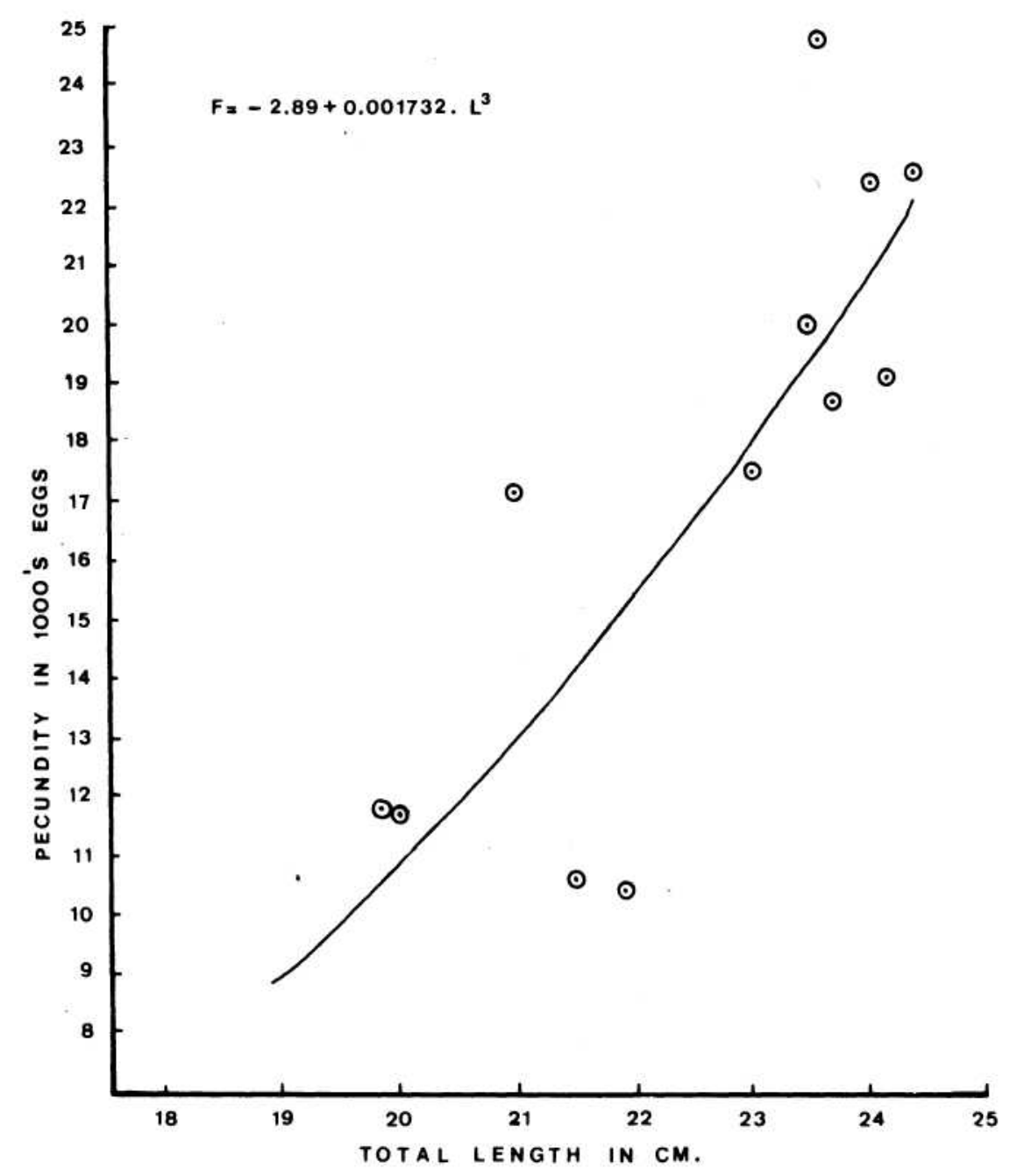

Figure 7. Total length - fecundity relationship for 1959-'60 season. 


\section{BIOLOGICAL STUDIES ON THE ANCHOVY}

Figure 8. Weight of fish - fecundity relationship for 1959-'60 season.

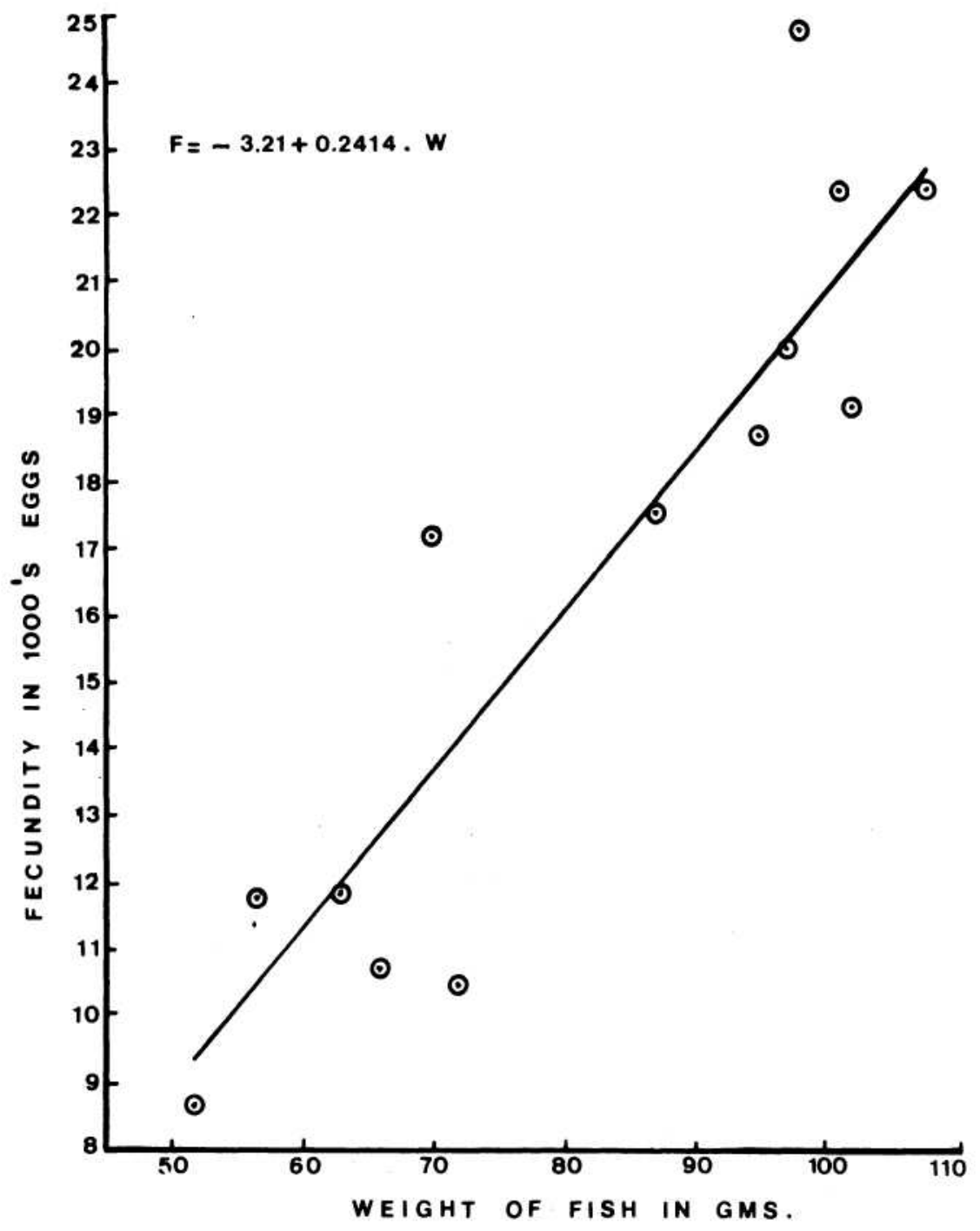




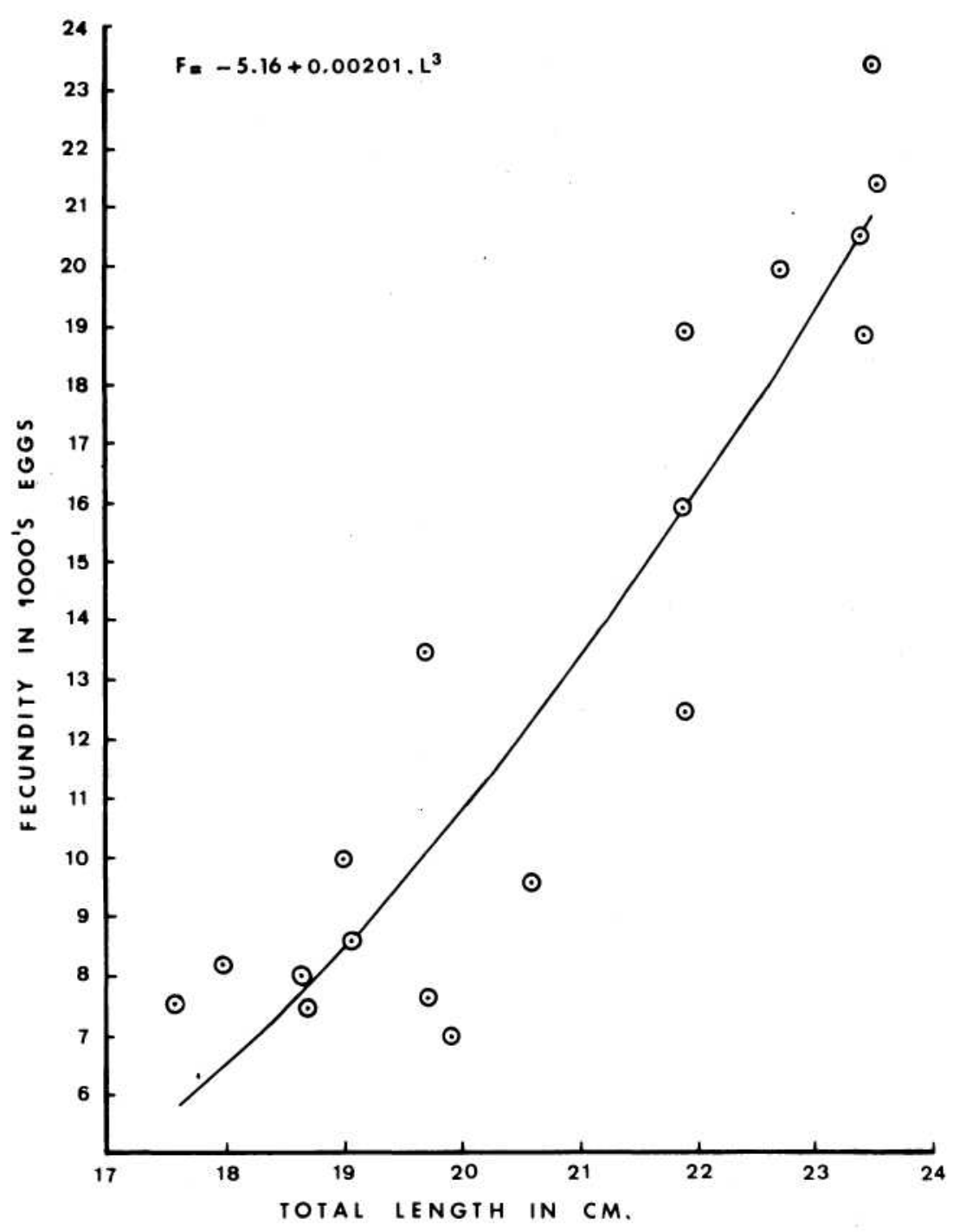

Figure 9. Total length - fecundity relationship for 1960-'61 season. 
BIOLOGICAL STUDIES ON THE ANCHOVY

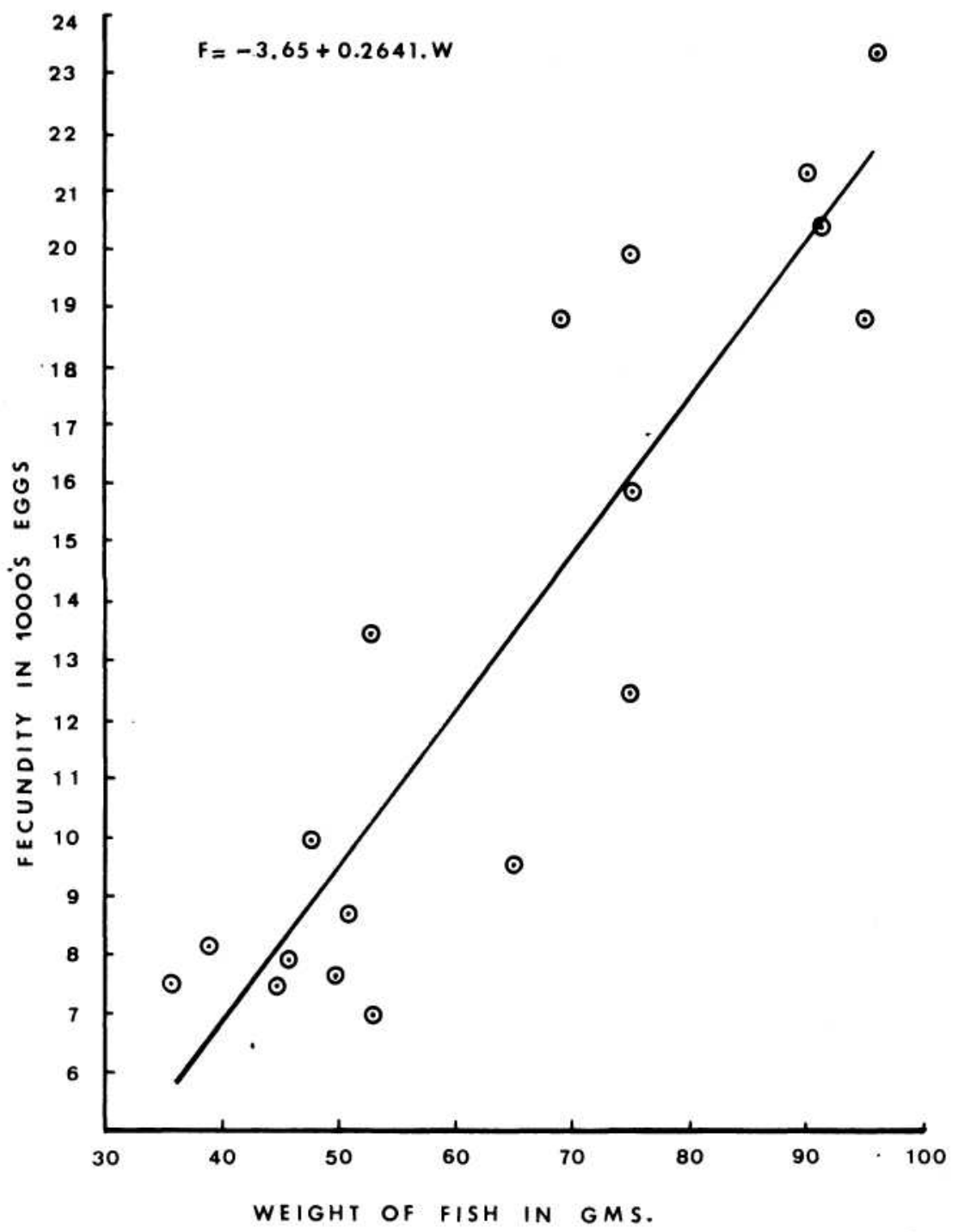

Figure 10. Weight of fish - fecundity relationship for 1960 - '61 season. 


\section{BABU RAO}

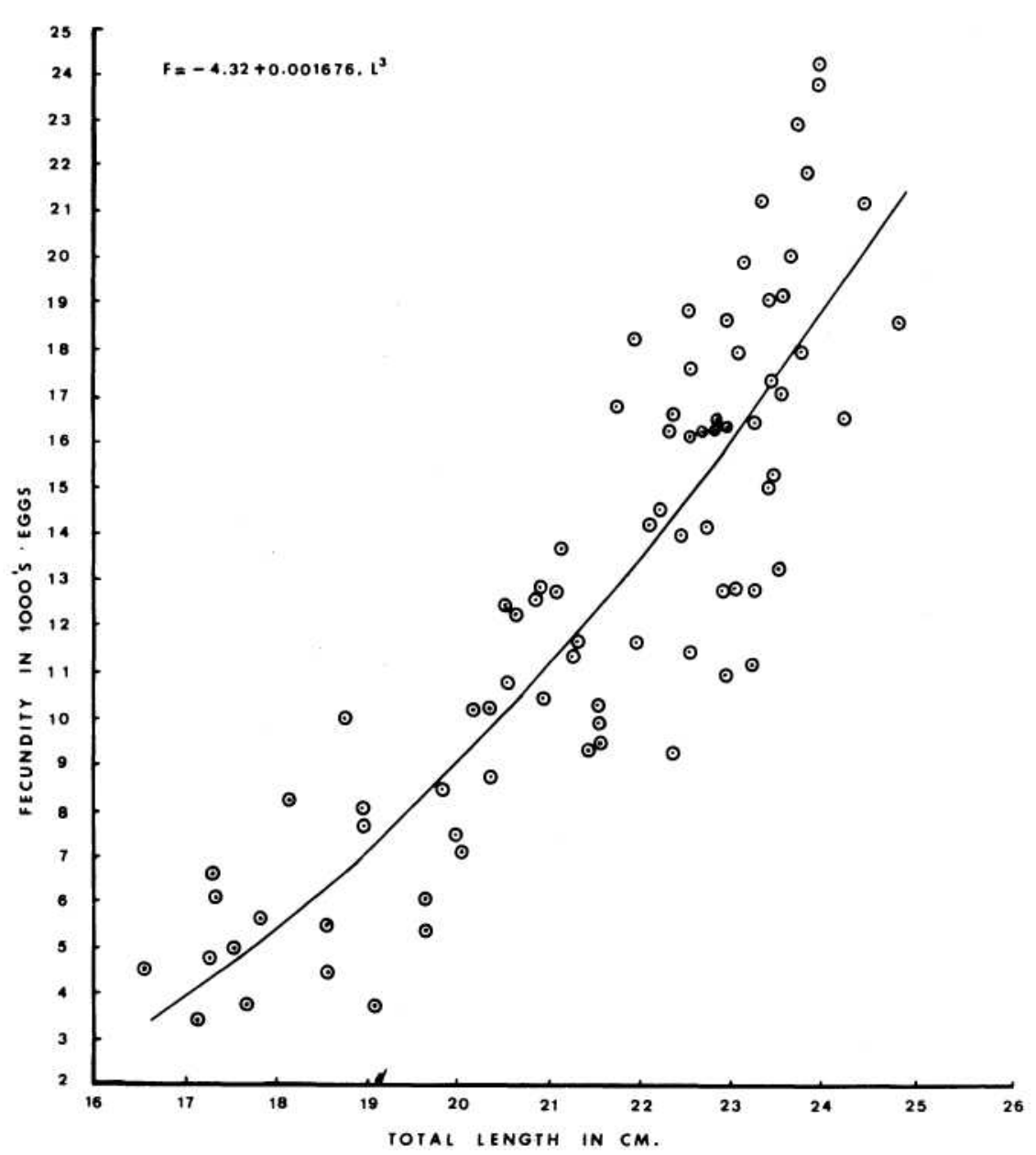

Figure II. Total length - fecundity relationship for 1961-'62 season.

organisms (in order of maximum occurrence) that constitute the food of this species were prawns, crustacean larvae, fish, young molluscs, copepods, polychaets, isopods and amphipods. Nematode and trematode parasites were also found in the guts. Many guts contained digested material and a few empty guts were also encountered (Table XV). Prawns mainly belonged to the genera Acetes, Metapeneus and Leander. Crustacean larvae were mainly Megalopa and Lucifer and a few Zoea. Fishes belonged to the genera Stolephorus, Leiognathus, Sciaena and Gerres. 
BIOLOGICAL STUDIES ON THE ANCHOVY

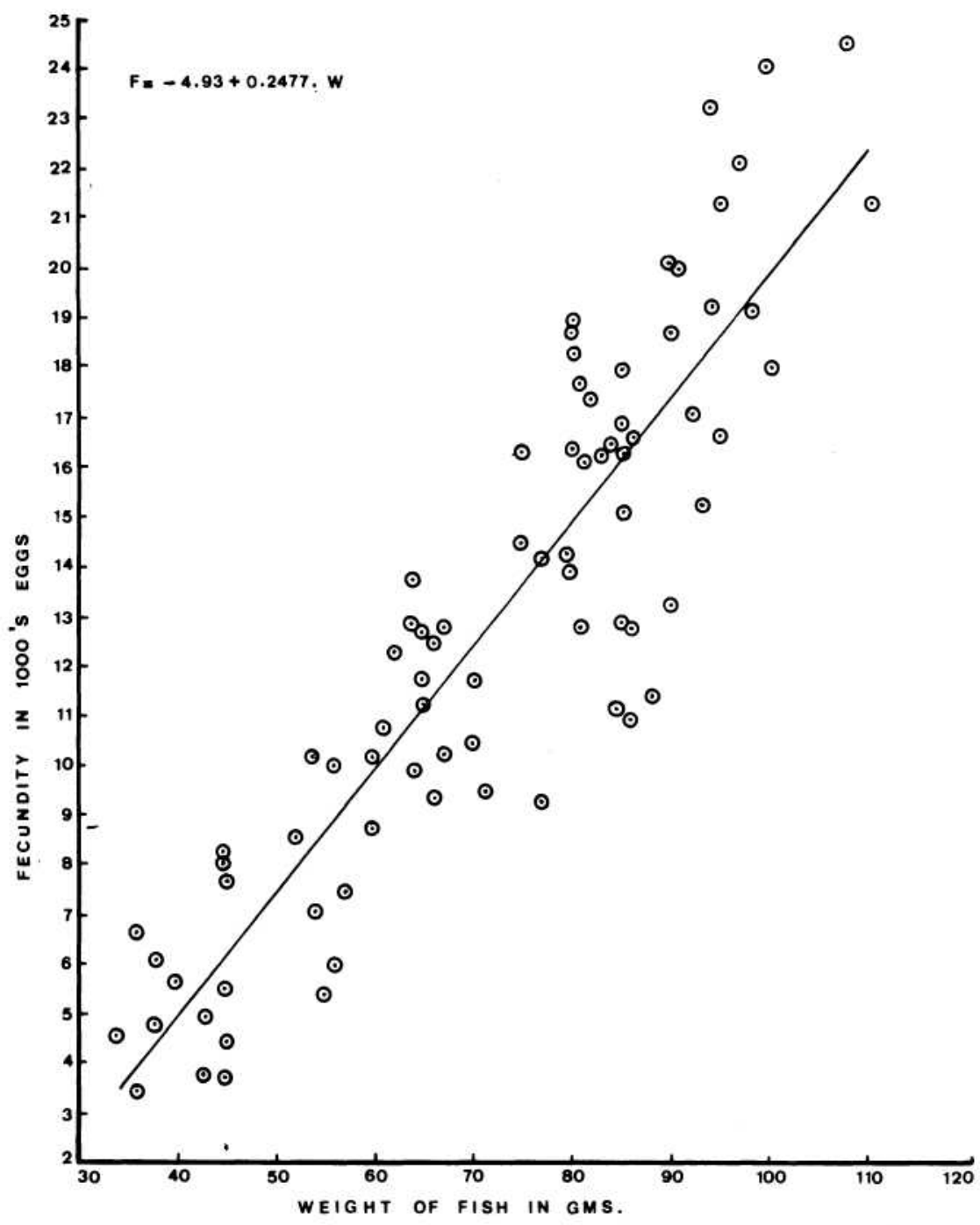

Figure 12. Weight of fish - fecundity relationship in 1961 - '62 season.

In its feeding habits this species seems to be predatory on pelagic organisms since its food mainly constitutes of Crustacean larvae. In view of the relatively few gill rakers, situated at considerable distance from one another, the gills are not suitable to filter the phytoplankton and hence phytoplankton did not form the food item in its guts. 


\section{BABU RAO}

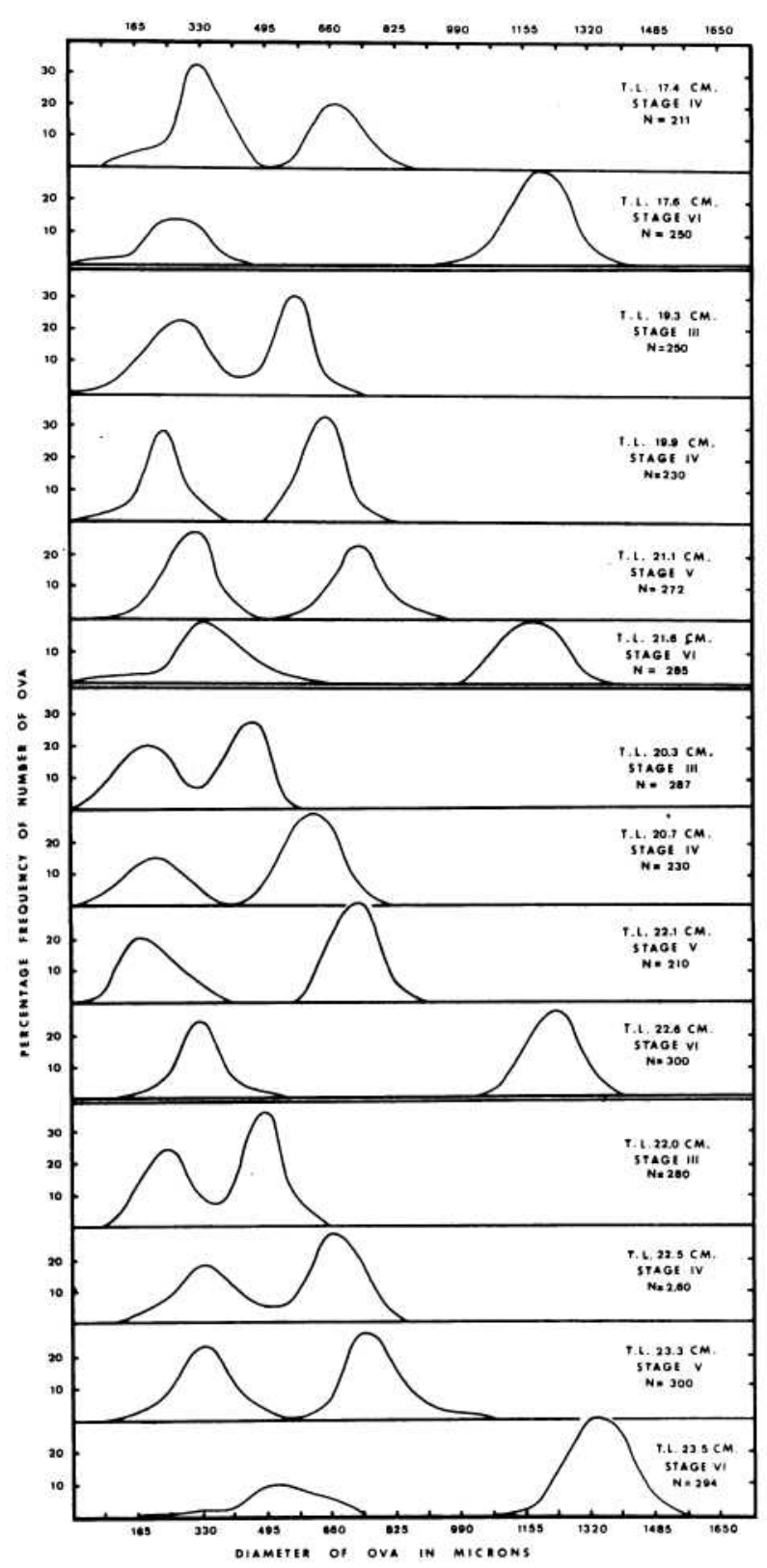

Figure 13. Percentage frequency curves of the ove diameters of the various female maturity stages in fishes of different lengths in the 1961-'62 season. 
BIOLOGICAL STUDIES ON THE ANCHOVY

TABLE X. Observed and calculated fecundity in fishes of different lengths and weights for the 1959'60 season

\begin{tabular}{|c|c|c|c|c|c|c|c|}
\hline \multirow[t]{2}{*}{ S. No. } & \multirow{2}{*}{$\begin{array}{l}\text { Total length } \\
\text { in } \mathrm{cm} \text {. }\end{array}$} & \multicolumn{2}{|c|}{ Fecundity } & \multirow[t]{2}{*}{ S No } & \multirow{2}{*}{$\frac{\text { Weight of fish }}{\text { in gms. }}$} & \multicolumn{2}{|c|}{ Fecundity } \\
\hline & & Observed & Calculated & & & Observed & Calculated \\
\hline 1. & 18.90 & 8,670 & 8,800 & 1. & 52 & 8,670 & 9,340 \\
\hline 2. & 19.90 & 11,810 & 10,770 & 2. & 57 & 11,710 & 10.550 \\
\hline 3. & 20.00 & 11,710 & 10,970 & 3. & 63 & 11,810 & 12,000 \\
\hline 4. & 21.00 & 17,200 & 13,140 & 4. & 66 & 10,660 & 12,720 \\
\hline 5. & 21.50 & 10,660 & 14,320 & 5. & 70 & 17,200 & 13,690 \\
\hline 6. & 21.90 & 10,430 & 15,300 & 6. & 72 & 10,430 & 14,170 \\
\hline 7. & 23.00 & 17,590 & 18,150 & 7. & 87 & 17,590 & 17,790 \\
\hline 8. & 23.50 & 20,040 & 19,600 & 8. & 95 & 18,730 & 19,720 \\
\hline 9. & 23.60 & 24,830 & 19,870 & 9. & 97 & 20,040 & 20,210 \\
\hline 10. & 23.70 & 18,730 & 20,140 & 10. & 98 & 24,830 & 20,440 \\
\hline 11. & 24.00 & 22,400 & 21,040 & 11. & 101 & 22,400 & 21,170 \\
\hline 12. & 24,15 & 19,140 & 21,490 & 12. & 102 & 19,140 & 21,410 \\
\hline 13. & 24.35 & 22,560 & 22,120 & 13. & 107 & 22,560 & 22,620 \\
\hline
\end{tabular}

TABLE XL Observed and calculated fecundity in fishes of different lengths and weights for the 1960'61 season.

\begin{tabular}{|c|c|c|c|c|c|c|c|}
\hline \multirow[t]{2}{*}{ S. .No. } & \multirow{2}{*}{$\begin{array}{l}\text { Total length } \\
\text { in } \mathrm{cm} .\end{array}$} & \multicolumn{2}{|c|}{ Fecundity } & \multirow[t]{2}{*}{ S No } & \multirow{2}{*}{$\begin{array}{c}\text { Weight of fish } \\
\text { in gms. }\end{array}$} & \multicolumn{2}{|c|}{ Fecundity } \\
\hline & & Observed & Calculated & & & Observed & Calculated \\
\hline 1. & 17.60 & 7,500 & 5,800 & 1. & 36 & 7,500 & 5,860 \\
\hline 2. & 18.00 & 8,100 & 6,560 & 2. & 39 & 8,100 & 6,650 \\
\hline 3. & 18.70 & 7,480 & 7,980 & 3. & 45 & 7,480 & 8,240 \\
\hline 4. & 18.70 & 7,920 & 7,980 & 4. & 46 & 7,920 & 8,500 \\
\hline 5. & 19.00 & 9,960 & 8,630 & 5. & 48 & 9,960 & 9,030 \\
\hline 6. & 19.10 & 8,630 & 8,850 & 6. & 50 & 7,610 & 9,550 \\
\hline 7. & 19.70 & 7,610 & 10,210 & 7. & 51 & 8,630 & 9,820 \\
\hline 8. & 19.70 & 13,430 & 10,210 & 8. & 53 & 6,990 & 10,350 \\
\hline 9. & 19.90 & 6,990 & 10,680 & 9. & 53 & 13,430 & 10,350 \\
\hline 10. & 20.60 & 9,520 & 12,420 & 10. & 65 & 9,520 & 13,520 \\
\hline 11. & 21.90 & 12.480 & 15,950 & 11. & 69 & 18,880 & 14,580 \\
\hline 12. & 21.90 & 15,930 & 15,950 & 12. & 75 & 12,480 & 16,160 \\
\hline 13. & 21.90 & 18,880 & 15,950 & 13. & 75 & 15,930 & 16,160 \\
\hline 14. & 22.70 & 19,950 & 18,350 & 14. & 75 & 19,950 & 16,160 \\
\hline 15 . & 23.40 & 18,860 & 20,580 & 15. & 90 & 21,360 & 20,120 \\
\hline 16. & 23.40 & 20,480 & 20,580 & 16. & 91 & 20,480 & 20,380 \\
\hline 17. & 23.50 & 21,360 & 20,940 & 17. & 95 & 18,860 & 21,440 \\
\hline 18. & 23.50 & 23,370 & 20,940 & 18. & 96 & 23,370 & 21,710 \\
\hline
\end{tabular}




\section{BABU RAO}

TABLE XII. Observed and calculated fecundity in fishes of different lengths for the 1961-'62 season.

\begin{tabular}{|c|c|c|c|c|c|c|c|}
\hline \multirow[t]{2}{*}{ SI..No. } & \multirow{2}{*}{$\begin{array}{l}\text { Total lenght } \\
\text { in } \mathrm{cm} .\end{array}$} & \multicolumn{2}{|c|}{ Fecundity } & \multirow[t]{2}{*}{ S.No. } & \multirow{2}{*}{$\begin{array}{c}\text { Total length } \\
\text { in } \mathrm{cm} .\end{array}$} & \multicolumn{2}{|c|}{ Fecundity } \\
\hline & & Observed & Calculated & & & Observed & Calculated \\
\hline 1. & 16.60 & 4,510 & 3,350 & 42. & 22.30 & 14,450 & 14,260 \\
\hline 2. & 17.20 & 3,400 & 4,210 & 43. & 22.40 & 9.230 & 14.500 \\
\hline 3. & 17.30 & 4,710 & 4,350 & 44. & 22.40 & 16,280 & 14,500 \\
\hline 4. & 17.40 & 6,030 & 4,500 & 45. & 22.40 & 16,530 & 14,500 \\
\hline 5. & 17.40 & 6,600 & 4,500 & 46. & 22.50 & 13,950 & 14,770 \\
\hline 6. & 17.60 & 4,920 & 4.820 & 47. & 22.60 & 11,400 & 15,020 \\
\hline 7. & 17.70 & 3,760 & 4,970 & 48. & 22.60 & 16.100 & 15,020 \\
\hline 8. & 17.90 & 5,600 & 5,290 & 49. & 22.60 & 17,640 & 15,020 \\
\hline 9. & 18.20 & 8,210 & 5,780 & 50. & 22.60 & 18,900 & 15.020 \\
\hline 10. & 18.60 & 4,460 & 6,460 & 51. & 22.70 & 16,200 & 15,280 \\
\hline 11. & 18.60 & 5,500 & 6,460 & 52. & 22.80 & 14,180 & 15,540 \\
\hline 12. & 18.80 & 10,000 & 6,820 & 53. & 22.80 & 16,280 & 15,540 \\
\hline 13. & 19.00 & 7,050 & 7,170 & 54. & 22.80 & 16,330 & 15,540 \\
\hline 14. & 19.00 & 8,030 & 7,170 & 55. & 22.90 & 16,290 & 15,800 \\
\hline 15. & 19.10 & 3,720 & 7,360 & 56. & 23.00 & 10,930 & 16,070 \\
\hline 16. & 19.70 & 5,360 & 8,490 & 57. & 23.00 & 12,750 & 16,070 \\
\hline 17. & 19.70 & 6,000 & 8,490 & 58. & 23.00 & 18,700 & 16,070 \\
\hline 18. & 19.90 & 8,520 & 8,890 & 59. & 23.10 & 12,780 & 16,330 \\
\hline 19. & 20.00 & 7,430 & 9,090 & 60. & 23.10 & 17,980 & 16,330 \\
\hline 20. & 20.10 & 7,040 & 9,290 & 61. & 23.20 & 19,950 & 16,600 \\
\hline 21. & 20.30 & 10,130 & 9,700 & 62. & 23.30 & 11,180 & 16,880 \\
\hline 22. & 20.40 & 8,750 & 9,900 & 63. & 23.30 & 12,860 & 16,880 \\
\hline 23. & 20.40 & 10,140 & 9,900 & 64. & 23.30 & 16,470 & 16,880 \\
\hline 24. & 20.60 & 10,730 & 10,330 & 65. & 23.40 & 21,270 & 17,190 \\
\hline 25. & 20.60 & 12,410 & 10,330 & 66. & 23.50 & 15,080 & 17,430 \\
\hline 26. & 20.70 & 12,290 & 10,550 & 67. & 23.50 & 15,210 & 17,430 \\
\hline 27. & 20.90 & 12,690 & 10,980 & 68. & 23.50 & 17,390 & 17,430 \\
\hline 28. & 21.00 & 10,450 & 11,200 & 69. & 23.50 & - 19,130 & 17,430 \\
\hline 29. & 21.00 & 12,780 & 11,200 & 70. & 23.60 & 13,260 & 17,710 \\
\hline 30. & 21.10 & 12,730 & 11,420 & 71. & 23.60 & 17,080 & 17,710 \\
\hline 31. & 21.20 & 13,700 & 11,640 & 72. & 23.60 & 19.200 & 17,710 \\
\hline 32. & 21.30 & 11,200 & 11,870 & 73. & 23.70 & 20,020 & 17,980 \\
\hline 33. & 21.30 & 11,700 & 11,870 & 74. & 23.80 & 18,000 & 18,270 \\
\hline 34. & 21.50 & 9,300 & 12,330 & 75. & 23.80 & 23.200 & 18,270 \\
\hline 35. & 21.60 & 9,440 & 12,580 & 76. & 23.90 & 22,100 & 18,560 \\
\hline 36. & 21.60 & 9,900 & 12,580 & 77. & 24.00 & 24,030 & 18,840 \\
\hline 37. & 21.60 & 10,230 & 12,580 & 78. & 24.00 & 24,530 & 18,840 \\
\hline 38. & 21.80 & 16,800 & 13,050 & 79. & 24.30 & 16,570 & 19,720 \\
\hline 39. & 22.00 & 11,680 & 13,520 & 80. & 24.50 & 21,230 & 20,330 \\
\hline 40. & 22.20 & 18,290 & 13,520 & 81. & 24.00 & 18,700 & 21,550 \\
\hline 41. & 22.20 & 14,150 & 14,020 & & & & \\
\hline
\end{tabular}


BIOLOGICAL STUDIES ON THE ANCHOVY

TABLE XIII. Observed and calculated fecundity in fishes of different weights for the 1961-'62 season.

\begin{tabular}{|c|c|c|c|c|c|c|c|}
\hline \multirow[b]{2}{*}{ S.No. } & \multirow{2}{*}{$\begin{array}{l}\text { Weight of fish } \\
\text { in gms. }\end{array}$} & \multicolumn{2}{|c|}{ Fecundity } & & \multirow{2}{*}{$\begin{array}{l}\text { Weight of fish } \\
\text { in gms. }\end{array}$} & \multicolumn{2}{|c|}{ Fecundity } \\
\hline & & Observed & Calculated & S.NO. & & Observed & Calculated \\
\hline 1. & 34 & 4,510 & 3,490 & 42. & 77 & 14,150 & 14,130 \\
\hline 2. & 36 & 3,400 & 3,990 & 43. & 80 & 13,950 & 14,880 \\
\hline 3. & 36 & 6,600 & 3,990 & 44. & 80 & 14,180 & 14,880 \\
\hline 4. & 38 & 4,710 & 4,480 & 45. & 80 & 16,330 & 14,880 \\
\hline 5. & 38 & 6,030 & 4,480 & 46. & 80 & 18,290 & 14,880 \\
\hline 6. & 40 & 5,600 & 4,980 & 47. & 80 & 18,700 & 14,880 \\
\hline 7. & 43 & 3,760 & 5,720 & 48. & 80 & 18,900 & 14,880 \\
\hline 8. & 43 & 4,920 & 5,720 & 49. & 81. & 12,750 & 15,120 \\
\hline 9. & 45 & 3,720 & 6,210 & 50. & 81 & 16,100 & 15,120 \\
\hline 10. & 45 & 4,460 & 6,210 & 51. & 81 & 17,640 & 15,120 \\
\hline 11. & 45 & 5,500 & 6,210 & 52. & 82 & 17,390 & 15,380 \\
\hline 12. & 45 & 7,650 & 6,210 & 53. & 83 & 16,280 & 15,620 \\
\hline 13. & 45 & 8,030 & 6,210 & 54. & 84 & 16,470 & 15,870 \\
\hline 14. & 45 & 8,210 & 6,210 & 55. & 85 & 11,180 & 16,120 \\
\hline 15. & 52 & 8,520 & 7,940 & 56. & 85 & 12,860 & 16,120 \\
\hline 16. & 54 & 7,040 & 8,450 & 57. & 85 & 15.080 & 16,120 \\
\hline 17. & 54 & 10,140 & 8,450 & 58. & 85 & 16.200 & 16,120 \\
\hline 18. & 55 & 5,360 & 8,690 & 59. & 85 & 16,290 & 16,120 \\
\hline 19. & 56 & 6,000 & 8,940 & 60. & 85 & 16,800 & 16,120 \\
\hline 20. & 56 & 10,000 & 8,940 & 61. & 85 & 17,980 & 16,120 \\
\hline 21. & 57 & 7,430 & 9,180 & 62. & 86 & 10,930 & 16,360 \\
\hline 22. & 60 & 8,750 & $\mathbf{9 , 9 3 0}$ & 63. & 86 & 12,780 & 16,360 \\
\hline 23. & 60 & 10,130 & $\mathbf{9 , 9 3 0}$ & 64. & 86 & 16,530 & 16,360 \\
\hline 24. & 61 & 10,170 & 10,170 & 65. & 88 & 11,400 & 16,860 \\
\hline 25. & 62 & 12,290 & 10,430 & 66. & 90 & 13,260 & 17,350 \\
\hline 26. & 64 & 9,900 & 10,920 & 67. & 90 & 18,700 & 17,350 \\
\hline 27. & 64 & 12,780 & 10,920 & 68. & 90 & 20,020 & 17,350 \\
\hline 28. & 64 & 13,700 & 10,920 & 69. & 91 & 19,950 & 17,600 \\
\hline 29. & 65 & 11,200 & 11,170 & 70. & 92 & 17,080 & 17,850 \\
\hline 30. & 65 & $11 / 700$ & 11,170 & 71. & 93 & 15,210 & 18,100 \\
\hline 31. & 65 & 12,690 & 11,170 & 72. & 94 & 19,200 & 18,350 \\
\hline 32. & 66 & 9,300 & 11,410 & 73. & 94 & 23.200 & 18,350 \\
\hline 33. & 66 & i2,410 & 11,410 & 74. & 95 & 16,570 & 18,350 \\
\hline 34. & 67 & 10,230 & 11,660 & 75. & 97 & 21,270 & 18,600 \\
\hline 35. & 67 & 12,730 & 11,660 & 76. & 98 & 22,100 & 19,090 \\
\hline 36. & 70 & 10,450 & 12,410 & 77. & 98 & 19,130 & 19,340 \\
\hline 37. & 70 & 11,680 & 12,410 & 78. & 100 & 18,000 & 19,340 \\
\hline 38. & 71 & 9,440 & 12,650 & 79. & 100 & 24,030 & 19,840 \\
\hline 39. & 75 & 14,450 & 13,650 & 80. & 108 & 24,530 & 21,810 \\
\hline 40. & 75 & 16,280 & 13,650 & 81. & 110 & 21,230 & 22,310 \\
\hline 41. & 77 & 9,230 & 14,130 & & & & \\
\hline
\end{tabular}


M. B ABU RAO

TABLE XIV. Equation expressing the relationship between total length and weight of the fish on one hand and fecundity on the other, in the three seasons.

\begin{tabular}{|c|c|c|c|c|c|}
\hline \multicolumn{2}{|c|}{ Season } & $\mathbf{n}$ & Equation & $\mathbf{n}$ & Equation \\
\hline 1959 & -160 & 13 & $F=-2.89+0.001732 . L^{3}$ & 13 & $F=-3.21+0.2414 . W$ \\
\hline 1960 & $-' 61$ & 18 & $F=-5.16+0.00201 . L^{3}=$ & 18 & $F=-3.65+0.2641 . W$ \\
\hline 1961 & $-' 62$ & 81 & F $-4.32+0.001676 . L^{3}$ & 81 & $F=\_4.93+0.2477 . W$ \\
\hline
\end{tabular}

\section{SUMMARY}

Biology of the anchovy Thryssa \& autamiensis in the Godavari estuary for the three seasons 1959-'60, 1960-'61 and 1961-'62, was studied. Percentage length frequency curves for the various months of the three seasons have shown that majority of adults occur during November February period and majority of juveniles occur in March - July period. When normal curves were fitted to the 1961-'62 data, it was found that in each month there were several normal curves indicating the existence of many populations, which were the offspring of broods of different periods.

Length-weight studies for the three seasons have shown that the best fit equation to express the two factors was $W=a+b . L^{3}$. Application of analysis of covariance to the length-weight data of the three seasons has revealed that 1960 - 61 season significantly differed from the rest of the two seasons in having a low regression coefficient.

Relative condition ('Kn') variation studies have shown that ' $K n$ ' values were higher during September to January from whence it decreased through February to April; from May onwards and increase of ' $\mathrm{Kn}$ ' was recorded. Among female individuals ' $\mathrm{Kn}$ ' was found to fluctuate from $16 \mathrm{~cm}$ onwards to the end. Since it was shown that maturing ovaries have a significant influence on the ' $K n$ ' values of the females, this fluctuation from $16 \mathrm{~cm}$ onwards might be due to the maturity and spawning, in the females, which start after $16 \mathrm{~cm}$ onwards.

Variations of fecundity with total length and weight of the fish were studied for the three seasons; the equations $F=\mathbf{a}+\mathbf{b} . \mathbf{L}^{3}$ and $F=\mathbf{a}+\mathbf{b} . \mathrm{W}$ were found to express the relationship between fecundity on one hand and total length and weight of the fish respectively on the other. Mature specimens were encountered after $16.0 \mathrm{~cm}$ onwards.

Ova diameter measurement studies for the 1961-'62 season have shown that fully mature specimens were found to occur from $17 \mathrm{~cm}$ to $24 \mathrm{~cm}$ indicating prolonged spawning in the species. The size of ova at Stage 
TABLE XV. Monthly percentage frequencies of the guts containing the listed food components for the 1960 - 61 season.

\begin{tabular}{|c|c|c|c|c|c|c|c|c|c|c|c|}
\hline $\begin{array}{l}\text { Name of the } \\
\text { food item }\end{array}$ & $\begin{array}{l}\text { Sept. } \\
1960 \\
n=10\end{array}$ & $\begin{array}{l}\text { Oct. } \\
1960 \\
n=31\end{array}$ & $\begin{array}{l}\text { Nov. } \\
1960 \\
\mathrm{n}=85\end{array}$ & $\begin{array}{l}\text { Dec. } \\
1960 \\
n=46\end{array}$ & $\begin{array}{r}\text { Jan. } \\
1961 \\
\mathrm{n}=23\end{array}$ & $\begin{array}{l}\text { Feb. } \\
1961 \\
n=23\end{array}$ & $\begin{array}{l}\text { March } \\
1961 \\
n=20\end{array}$ & $\begin{array}{l}\text { April } \\
1961 \\
n=12\end{array}$ & $\begin{array}{l}\text { May } \\
1961 \\
\text { n-30 }\end{array}$ & $\begin{array}{l}\text { June } \\
1961 \\
n=16\end{array}$ & $\begin{array}{l}\text { Average } \\
\text { percentage } \\
\text { for the season }\end{array}$ \\
\hline Prawns & 20.0 & 26.0 & 48.2 & 47.8 & 40.0 & 34.8 & 30.0 & 33.3 & 56.7 & 68.8 & 30.9 \\
\hline Megalopa & 80.00 & - & 23.5 & 32.6 & 55.0 & 8.7 & 5.0 & - & - & - & 15.6 \\
\hline $\begin{array}{l}\text { Lucifer } \\
\text { Other Crustacean }\end{array}$ & - & 3.2 & 2.4 & 2.2 & - & - & - & - & 10.0 & 6.3 & 1.8 \\
\hline larvae & - & - & - & - & - & & 10.0 & & & & 0.8 \\
\hline Fish & 10.0 & 26.0 & 22.4 & 17.4 & 20.0 & 13.0 & 10.00 & 25.0 & 23.3 & 25.0 & 14.6 \\
\hline Young Gastropods & - & - & - & - & - & 4.3 & - & 16.7 & 6.7 & - & 2.1 \\
\hline Young Bivalves & - & - & - & - & - & - & - & 8.3 & 26.7 & 6.3 & 3.2 \\
\hline Copepods & - & 13.0 & - & 2.2 & - & 4.3 & - & - & 6.7 & _ & 2.0 \\
\hline Polychaetes & - & 3.2 & - & - & - & - & - & - & - & 6.3 & 0.7 \\
\hline Isopods & - & - & 7.1 & 2.2 & - & - & - & - & - & - & 2.6 \\
\hline Amphipods & - & 6.5 & - & - & - & - & - & - & - & - & 1.8 \\
\hline $\begin{array}{l}\text { Digested material } \\
\text { Parasites }\end{array}$ & - & 16.1 & 15.3 & 4.3 & 10.0 & 34.8 & 55.0 & 8.3 & 13.3 & 18.8 & 13.4 \\
\hline Nematodes & - & 6.5 & 1.5 & - & - & - & - & 16.7 & 3.3 & 6.3 & 2.6 \\
\hline Trematodes & 10.0 & 9.7 & 4.7 & 4.3 & 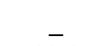 & $1 \overline{3} .0$ & $\overline{5.0}$ & & 6.7 & & 4.1 \\
\hline Empty Guts & - & 22.6 & 2.4 & 2.2 & 10.0 & 13.0 & 5.0 & 33.3 & 3.3 & & 7.0 \\
\hline
\end{tabular}




\section{BABU RAO}

III of maturity was $0.40-0.50 \mathrm{~mm}$, at Stage IV $0.60-0.70 \mathrm{~mm}$, at Stage V $0.70 \quad 0.80 \mathrm{~mm}$ and at Stage VI $1.00-1.40 \mathrm{~mm}$.

A study of the percentage frequency of the guts containing various food organisms in different months for 1960-'61 season has shown that the species prefers the following food organisms in the order mentioned: prawns, crustacean larvae, fish, young molluscs, copepods, polychaets, isopods and amphipods.

\section{ACKNOWLEDGEMENTS}

The author is greatly indebted to Profs. S. DutT and P.N. GANAPATI Department of Zoology, Andhra University, for their constant guidance and interest during the course of this investigation and to the Indian Council of Agricultural Research for the financial grants.

\section{REFERENCES}

BABU RAO, M. 1964. Some observations on the biology of Hilsa anagurta (BLEEKER) (Fam: Clupeidae). Ichthyologica 3 : 63-76.

1965. Biological studies on the Gizzard shad Anodontostoma chacunda (HAMILTON) (Fam: Clupeidae)/ Mar. biol. Ass. India 1: 89-101.

1971. A new anchovy, Thryssa gautamiensis sp. nov. (Pisces: Engraulidae) from the Godavari estuary, India. Copeia 3 : 479—483.

CASSIE, R.M. 1954. Some uses of probability paper in the analysis of size frequency distributions. Aust. J. Mar. Fresh W. Res. 5: 515-522.

GOULDEN, C.H. 1939. Methods of Statistical Analysis. J. Wiley and Sons Inc., New York.

HARDING, J.P. 1949. The use of probability paper for the graphical analysis of polymodal frequency distributions. $J$. mar. biol Ass. U.K. 25 : 141-153.

LE CREN, E.D. 1951. The length weight relationship and seasonal cycle in gonad weight and condition in perch (Perca fluviatilis). J. Anim. Ecol. 20: 201-219.

PILLAY, T.V.R. 1958. Biology of the Hilsa, Hilsa ilisha (HAMILTON) of the river Hooghly. Indian J. Fish. 5: 201-257. 